\title{
The gene for trypsin inhibitor CMe is regulated in trans by the lys $3 a$ locus in the endosperm of barley (Hordeum vulgare $\mathbf{L}$.)
}

\author{
Pahlo Rodriguez-Palenzuela, Joaquin Royo, Luis Gómez, Rosa Sánchez-Monge, Gahriel Salcedo, \\ José Luis Molina-Cano*, Francisco Garcia-Olmedo, and Pilar Carbonero \\ Cátedra de Bioquimica y Biologia Molecular, ETS, Ingenieros Agrónomos-UPM, E-28040 Madrid, Spain
}

\begin{abstract}
Summary. A cDNA encoding trypsin inhibitor CMe from barley endosperm has been cloned and characterized. The longest open reading frame of the cloned cDNA codes for a typical signal peptide of 24 residues followed by a sequence which is identical to the known amino acid sequence of the inhibitor, except for an Ile/Leu substitution at position 59. Southern blot analysis of wheat-barley addition lines has shown that chromosome $3 \mathrm{H}$ of barley carries the gene for $\mathrm{CMe}$. This protein is present at less than $2 \%-3 \%$ of the wild-type amount in the mature endosperm of the mutant Risg 1508 with respect to Bomi barley, from which it has been derived, and the corresponding steady state levels of the CMe mRNA are about $1 \%$. One or two copies of the CMe gene (synonym Itc1) per haploid genome have been estimated both in the wild type and in the mutant, and DNA restriction patterns are identical in both stocks, so neither a change in copy number nor a major rearrangement of the structural gene account for the markedly decreased expression. The mutation at the $l y s 3 a$ locus in Risø 1508 has been previously mapped in chromosome 7 (synonym $5 \mathrm{H}$ ). A single dose of the wild-type allele at this locus (Lys 3a) restores the expression of gene CMe (allele CMe-1) in chromosome $3 \mathrm{H}$ to normal levels.
\end{abstract}

Key words: Trypsin inhibitor - Gene regulation - lys $3 a$ locus - Barley

\section{Introduction}

Mutations affecting the overall lysine content of cereal endosperm have received considerable attention because lysine is the limiting essential amino acid in cereal grains when used as food for monogastric animals (Mertz et al. 1964; Nelson et al. 1965; Munck et al. 1970; Singh and Axtell 1973; Ingversen et al. 1973; Doll 1973, 1983, 1984). However, these so-called high-lysine mutations do not specifically affect lysine biosynthesis and their effect on lysine content is the indirect result of profound alterations in the pattern of protein accumulation throughout development and, at least in some cases, they also affect the metabolism of carbohydrates and lipids, as well as seed morphology.
A common feature of many of these mutants is a decrease in the level of storage prolamins and it has been suggested that they should be considered as low-prolamin rather than high-lysine mutants (Doll 1984). In barley, three such mutations have been most extensively studied: (1) a spontaneous mutation in the $l y s$ locus of Hiproly barley, which was identified in a screening of the world barley collection (Munck et al. 1970); (2) a mutation affecting the $l y s 3 a$ locus in mutant Rise 1508, which was induced experimentally from cv. Bomi (Doll et al. 1974); and (3) the Hor-2ca mutation in Risø 56, obtained by $\gamma$-ray treatment of Carlsberg II barley (Doll 1980). While a major portion of the $B$ hordein structural genes at the Hor-2 locus has been deleted in Riso 56 (Kreis et al. 1983), in the other two mutations, both of which map in separate loci of chromosome 7 (synonym SH; Karlsson 1976, 1977), trans-acting regulatory genes seem to be affected (Doll 1984). The $l y s 3 a$ mutation drastically reduces the net accumulation of all hordein polypeptides except D-hordein (Ingversen et al. 1973; Hopp et al. 1983; Thompson and Bartels 1983; Kreis et al. 1984). The reduction in storage protein accumulation seems to bring about an increase in the synthesis of other polypeptides and in the level of free amino acids (Brandt 1976; Shewry et al. 1980). Hiproly and its high-lysine derivatives have also been reported to have a reduced prolamin production, although to a lesser extent than in Risø 1508, and a significant increase in other proteins, such as protein $\mathrm{Z}, \beta$-amylase, and two chymotrypsin inhibitors, CI-1 and CI-2 (Hejgaard and Boisen 1980; Boisen et al. 1981 ; Hejgaard 1982). In contrast, the genes for protein $Z$ and $\beta$-amylase are almost completely switched off by the lys $3 a$ mutation (Balasaraswathi et al. 1984; Kreis et al. 1987; Sorensen et al. 1989). We report here the molecular cloning of the cDNA corresponding to trypsin inhibitor $\mathrm{CMe}$ and present evidence that gene CMe (synonym Itc1; see Sogaard and von Wettstein-Knowles 1987) is regulated in trans by the lys $3 a$ locus.

\section{Materials and methods}

Biological material. The cultivated barley Hordeum vulgare cv. Bomi and its mutant Risø 1508 were the gift of $\mathrm{H}$. Doll (Risø Laboratory, Denmark). Disomic addition lines of Betzes barley in Chinese Spring wheat were donated by K. Shepherd (Adelaide, Australia). Barley cv. Hatif de Grignon was from La Cruz del Campo SA (Sevilla, Spain), where the crosses with Risø 1508 were carried out. A cDNA 
library from the endosperm of Hordeum vulgare $\mathrm{cv}$. Abissynian 2231 in the vector $\lambda$ NM1149 was the kind gift of W. Rohde (Max Planck Institute, Köln, FRG). B-hordein clone pB11 was provided by Dr. J. Forde (Rothamsted, UK).

Screening of the cDNA library. The library was screened with a 17 nucleotide degenerate synthetic probe as described by Woods et al. (1982). Prehybridization was in $6 \times$ SSC, $1 \times$ Denhardt's solution, $0.5 \%$ SDS, $0.05 \%$ sodium pyrophosphate, $100 \mu \mathrm{g} / \mathrm{ml}$ herring sperm DNA at $37^{\circ} \mathrm{C}$ for $2 \mathrm{~h}$ Hybridization was done overnight at the same temperature. The oligonucleotide was labeled with $\mathrm{T} 4$ polynucleotide kinase. The filters were washed at $37^{\circ} \mathrm{C}$ for $1 \mathrm{~h}$ with $3 \times \mathrm{SSC}$, $0.05 \%$ sodium pyrophosphate, followed by a stringent wash at $47^{\circ} \mathrm{C}$ for $10 \mathrm{~min}$. Large-scale preparation of purified recombinant phages was carried out according to Yamamoto et al. (1970).

DNA sequencing. DNA sequencing was carried out both by the dideoxy chain-termination method of Sanger et al. (1977) and by the chemical modification method of Maxam and Gilbert (1980). Appropriate fragments were subcloned in the $\mathrm{M} 13 \mathrm{mp} 18 / \mathrm{mp} 19$ or in the $\mathrm{pUC} 18 / 19$ vector systems as required.

Dot-blot analysis and filter hybridization. Isolation of DNA from dark-grown seedlings was according to Murray and Thompson (1980). Restriction digestions, agarose gel electrophoresis and Southern blotting to nylon membranes (Hybond N, Amersham) were performed by standard techniques (Maniatis et al. 1982) or according to the manufacturer's instructions. Hybridization with multiprimer-labeled probes (Feinberg and Vogelstein 1983) was in $5 \times$ SSPE, $2 \times$ Denhardt's solution, $0.2 \%$ SDS, $10 \mu \mathrm{g} / \mathrm{ml}$ herring sperm DNA at different temperatures.

Total RNA from developing endosperms and from coleoptiles was obtained by the hot-phenol procedure. Quantitation of CMe mRNA was by standard dot-blot analysis or by blotting the appropriate clones and hybridization with ${ }^{32} \mathrm{P}$-labeled total RNA as a probe (Domoney and Casey 1987).

Protein fractionation and analysis. Individual endosperms (ca. $30 \mathrm{mg}$ ) were delipidated and extracted with $0.5 \mathrm{M} \mathrm{NaCl}$ as previously described (Salcedo et al. 1984). The extracts were fractionated by high-performance liquid chromatography (HPLC) or by two-dimensional electrophoresis.

Fractionation by HPLC was on a Vydac TP.RP-C4 column at $1 \mathrm{ml} / \mathrm{min}$ with the following composite acetonitrile/ $\mathrm{H}_{2} \mathrm{O}$ linear gradient: starting buffer, $10 \%$ acetonitrile (0.1\% trifluoroacetic acid); up to $20 \%$ in $45 \mathrm{~min} ; 20 \%-35 \%$ in $140 \mathrm{~min} ; 35-50 \%$ in $100 \mathrm{~min} ; 50 \%-85 \%$ in $12 \mathrm{~min}$.

Fractionation by two-dimensional electrophoresis was essentially as follows: the first separation was by electrofocusing (IEF; ampholines $\mathrm{pH} \mathrm{4-9,5 \%}$ polyacrylamide; $2 \mathrm{~mm} \times 14 \mathrm{~mm}$ columns; $7 \mathrm{~h}$ at $470 \mathrm{~V}$; samples inserted at acid end) and the second separation was by starch gel electrophoresis (SGE; $0.1 \mathrm{M}$ aluminium lactate buffer, $\mathrm{pH} 3.2$, $3 \mathrm{M}$ urea; $1 \mathrm{~mm} \times 18 \mathrm{~cm} \times 28 \mathrm{~cm}$ slabs; $4 \mathrm{~h}$ at $20 \mathrm{~V} / \mathrm{cm}$ and $5^{\circ} \mathrm{C}$ ). Gels were stained with $0.05 \%$ Nigrosine in methanol/ $\mathrm{H}_{2} \mathrm{O} /$ acetic acid (5:5:1, by volume).

\section{Results}

Characterization of a cDNA clone encoding trypsin inhibitor CMe

A cDNA library derived from barley endosperm at 14 days after pollination (dap) was screened with a 17 nucleotide
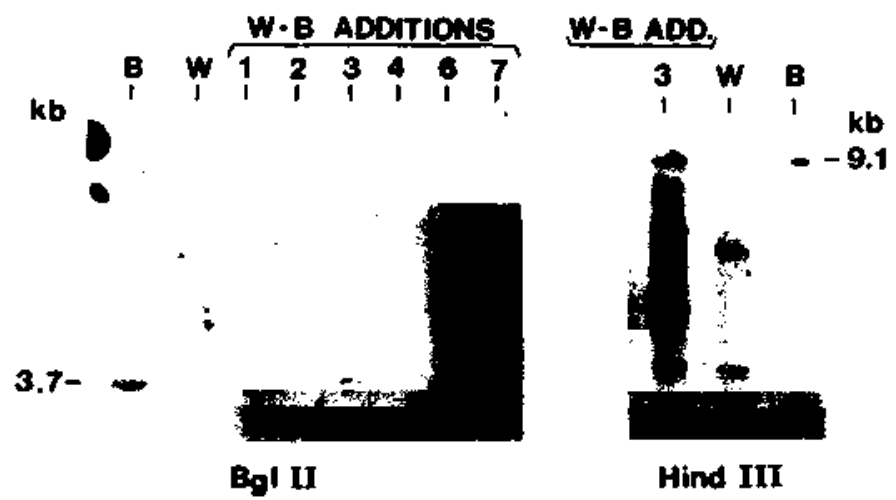

Fig. 1. Southern blot analysis, using the insert in clone $\lambda \mathrm{CMe}$ as a probe, of DNA from the following stacks: Betzes barley (B); Chinese Spring (W); Chinese Spring wheat/Betzes barley addition lines $(1,2,3,4,6,7)$. Line 5 was not available. DNA digested with restriction endonuclease $B g l \mathrm{II}$ was hybridized at $65^{\circ} \mathrm{C}$. Confirmation of the chromosome assignment was done with DNA digested with $H$ indIII and the hybridization was at lower stringency $\left(58^{\circ} \mathrm{C}\right) . \lambda \mathrm{DNA}$ digested with $\mathrm{HindIIl}$ (Boehringer) was used as molecular weight marker

\footnotetext{
TtGATAACAATGGCGTTCAAGTACCAGCTCCTCCTGTCGGCCGCCGTCATGCTCGCCATTCTCGTCGCCACTGCCACCAGtTtCGgGgatTCGTGTGCTCCAGGGGATGCGTTGCCACAC M A $F$ $\rightarrow$ Leader

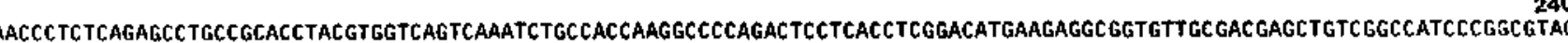
N P L R A C R T Y V V S Q I C H Q G P R L L T S D M K R R C C D E L S A I P A Y

Probe



480 GCCAACCTCGTCACCCCGCAGGAGTGCAACCTAGgGACCATCCACGGCAGCGCGTACTGCCCCGAACTGCAGCCCGCATATTGAGTGGTCTTGTAATAAGTTCTAACGACTACCTCGATC

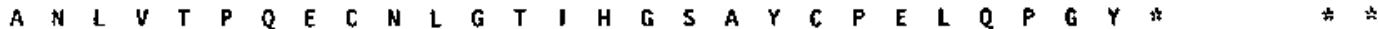

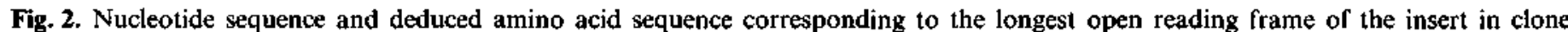

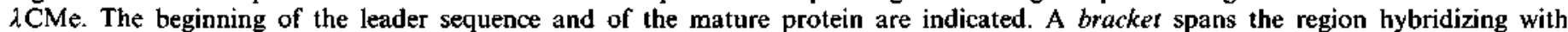


The AATAA polyadenylation signal is wnderlined. Stop codons are indicated with asterisks 
kb

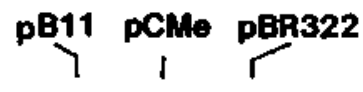

plasmid insert<smiles>[14CH3][V]</smiles>

3.58

3.28


Fig. 3. Amount of CMe mRNA relative to B-hordein mRNA in the endosperm of Bomi barley 18 days after pollination. Linearized plasmids were subjected to electrophoresis, transferred to a nylon membrane (Hybond $\mathrm{N}$, Amersham), and hybridized with ${ }^{32} \mathrm{P}$ RNA. After autoradiography, the bands were excised and their radioactivity estimated by liquid scintillation spectrometry. To correct for the difference in insert size the radioactivity $\left(4.6 \times 10^{4} \mathrm{cpm}\right)$ corresponding to pCMe was multiplied by the factor $0.88 / 0.58$

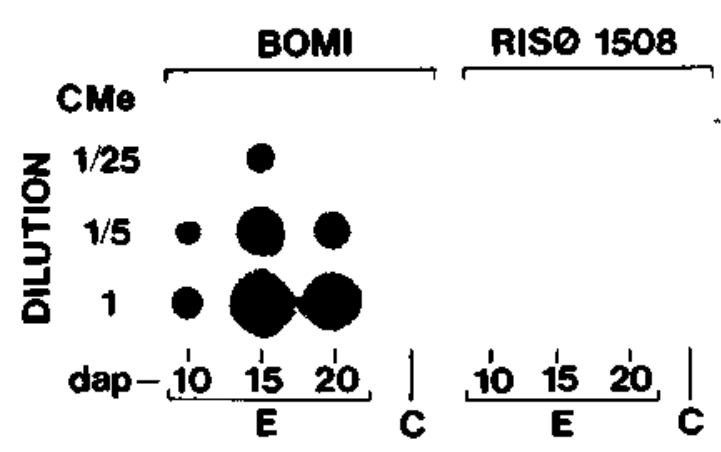

\section{BDAl-1}

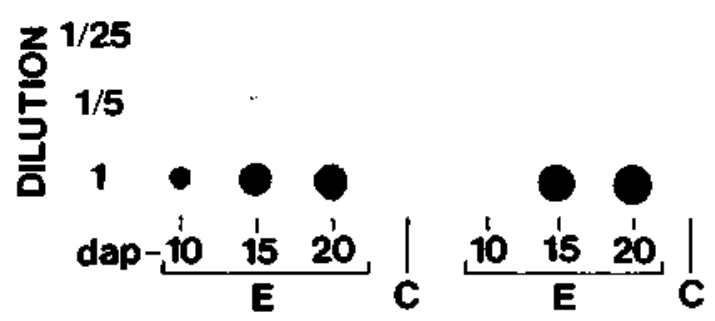

Fig. 4. Dot-blot quantitation of mRNAs corresponding to trypsin inhibitor CMe and barley dimeric $\alpha$-amylase inhibitor BDAI-1 in developing endosperm from barley cv. Bomi and its mutant Risø 1508. Dilution 1 corresponds to $10 \mu \mathrm{g}$ of total RNA. After the dot-blot experiment, the probe was washed and the filter hybridized again with a probe for rRNA. The dots were then excised and counted. Differences of total RNA between samples were $<10 \%$. Endosperms (E) at 10,15, and 20 days after pollination (dap) were analysed together with coleoptiles (C) as negative controls

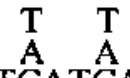

mixed probe (ATCATCATGCA $\stackrel{A}{A}$ GGXGT) corresponding to positions 61-66 of the published amino acid sequence of trypsin inhibitor CMe (Odani et al. 1983). The insert of a clone which hybridized with this probe, $\lambda \mathrm{CMe}$, was used for the Southern analysis of wheat-barley chromosomal addition lines, obtained by Islam et al. (1978), and thus found to hybridize with the DNA of barley chromosome $3 \mathrm{H}$, as shown in Fig. 1. This chromosome had been pre-

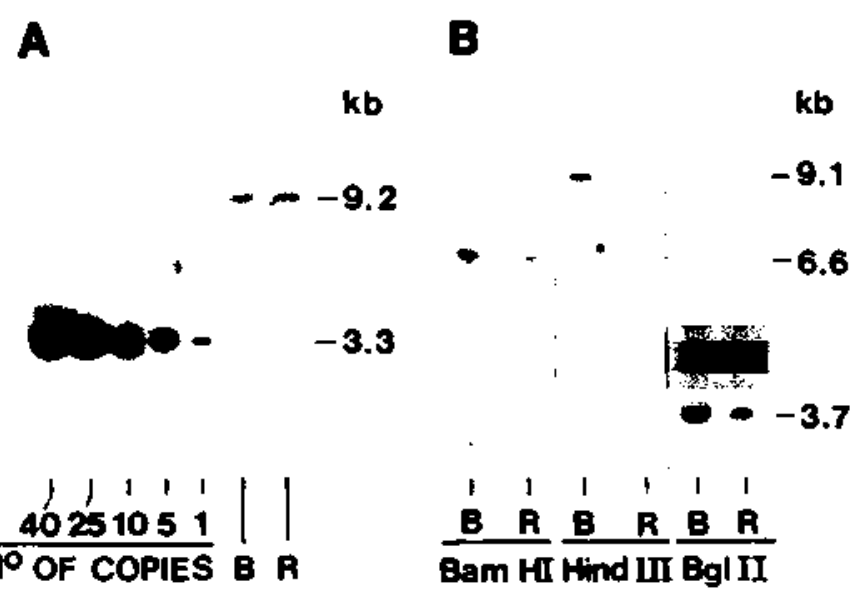

Fig. 5A. Number of copies of gene CMe in Bomi barley (B) and its mutant Riso 1508 (R). DNA digested with the restriction endonuclease $X b a I$. B Restriction patterns obtained with the indicated restriction endonucleases. Hybridization was carried out at $65^{\circ} \mathrm{C}$



Fig. 6. HPLC analysis of protein CMe in Bomi barley and its mutant Risø 1508. The same amount of dry endosperm (ca. $30 \mathrm{mg}$ ) was extracted with $\mathrm{NaCl}$ and analysed in both stocks. The CMe peak in Bomi is approximately equivalent to that obtained with $25 \mu \mathrm{g}$ of pure CMe protein. Only protein CMe was detected by two-dimensional electrophoresis of the HPLC peak

viously proposed as the site of gene $C M e$, based on the electrophoretic analysis of the protein (Salcedo et al. 1984; Hejgaard et al. 1984). The insert of clone $\lambda \mathrm{CMe}$ was subcloned and sequenced (Fig. 2). The deduced amino acid sequence corresponding to the longest open reading frame consisted of a typical signal peptide at the N-terminus, followed by a sequence that was identical to that obtained by direct protein sequencing of trypsin inhibitor $\mathrm{CMe}$ (Odani et al. 1983), except for a Leu/Ile substitution at position 59 of the mature protein. The presence of a signal 
peptide was expected from previous observations concerning other members of the same protein family (Paz-Ares et al. 1983, 1986; Lazaro et al. 1988a, b).

The subcloned CMe cDNA (pCME) was blotted onto a nitrocellulose filter together with a B-hordein $\mathrm{CDNA}$ and hybridized with radioactively labeled total RNA from Bomi endosperm (18 dap) and, after autoradiography, the appropriate zones of the filter were excised and counted (Fig. 3). The amount of CMe mRNA was thus estimated at about one-third of that of the mRNAs which hybridized with the B-hordein cDNA.

\section{Control of gene CMe by the lys $3 \mathrm{a}$ locus}

Relative steady-state levels of the CMe mRNA were determined during endosperm development, in cv. Bomi and its mutant Risø 1508, by dot-blot hybridization with CMe cDNA as the probe (Fig. 4, top). Maximum levels, which were reached before 20 dap, were about 100 -fold lower in the mutant with respect to the wild type. As a control, the same RNA samples were hybridized with a cDNA which encoded a different member of the same protein family, the barley dimeric inhibitor of heterologous $\alpha$-amylases BDAI-1 (Lazaro et al. $1988 \mathrm{~b}$ ). In that case, the mRNA level was higher in the mutant than in the wild type (Fig. 4, bottom).

The number of copies per haploid genome were 1-2 in both mutant and wild type (Fig. $5 \mathrm{~A}$ ), and the restriction patterns obtained with four restriction endonucleases were also identical in both stocks (Fig. 5A and B).

To resolve the apparent contradiction between the analysis by two-dimensional electrophoresis, which had not de-
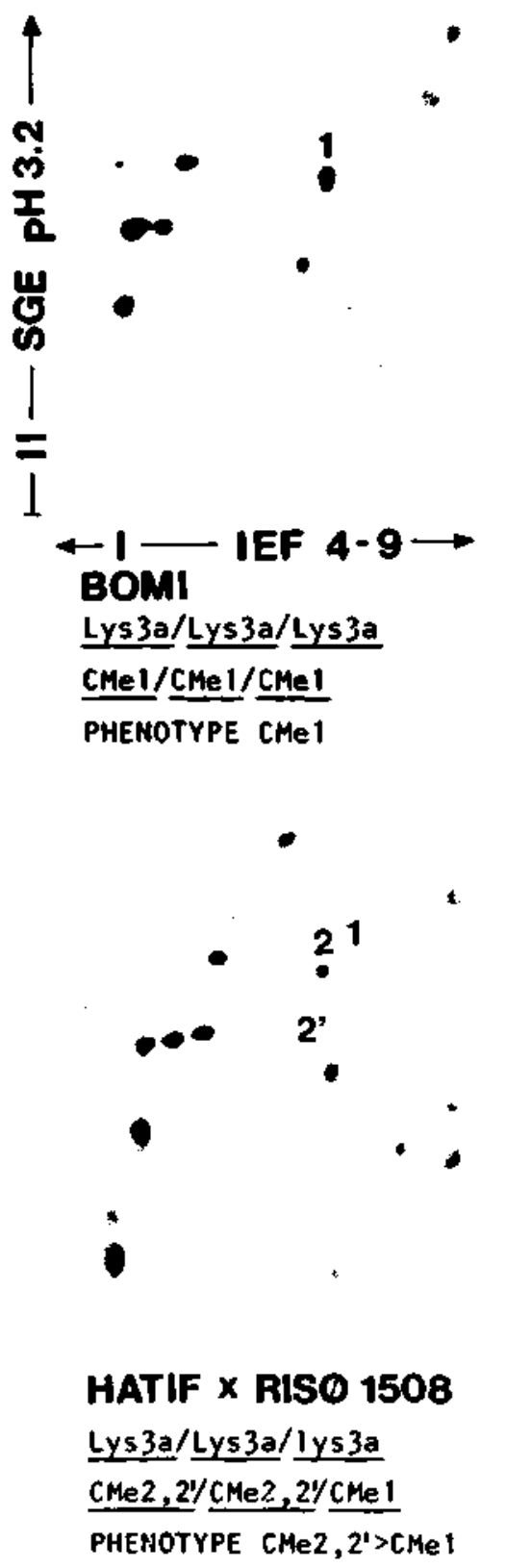



1

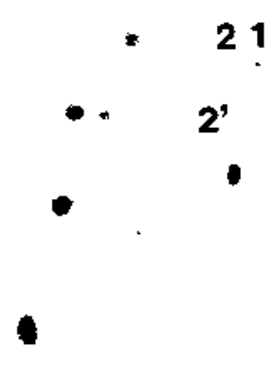

RISO $1508 \times$ HATIF

Iys 3a/lys3a/Lys3a

$\mathrm{CMe} 1 / \mathrm{CMe} 1 / \mathrm{CMe} 2,21$

PHENOTYPE CMe1>CMe2,2'
HATIF DE GRIGNON

Lys 3a/Lys3a/Lys3a

CMe2,2Y $\mathrm{CMe} 2,2 \mathrm{CMe} 2,2$

PHENOTYPE CME2, 2 '

Fig. 7. Analysis by combined isoelectrofocusing (IEF pH 4-9) and starch-gel electrophoresis (SGE pH 3.2) of 0.5 M NaCl extracts of the indicated stocks. Genotypes for the CMe and $l y s 3 a$ loci are listed in each case. Spots corresponding to variant CMe1 and $\mathrm{CMe} 2,2^{\prime}$ are indicated in the two-dimensional maps by 1,2 , and $2^{\prime}$, respectively 
tected any $\mathrm{CMe}$ inhibitor in the mutant (Salcedo et al. 1984), and that carried out by HPLC, which estimated the inhibitor level in the mutant as $20 \%$ that of the wild type (Lazaro et al. 1985), the analysis was repeated using a different HPLC column. As shown in Fig. 6, a Vydac TP-RPC4 column resolved protein CMe from minor overlapping proteins and allowed estimation of the maximum possible amount of inhibitor in the mutant as less than 2\%-3\% of the wild-type amount.

To ascertain that the mutagenesis treatment used to obtain mutant Rise 1508 had not affected gene $C M e$ itself, reciprocal crosses were carried out between the mutant and barley cv. Hatif de Grignon, which had been previously shown by Salcedo et al. (1984) to have a pair of variants of the inhibitor (CMe-2-2'), which did not overlap with the $\mathrm{CMe}-1$ variant prevailing in most $H$. vulgare cultivars surveyed, including cv. Bomi. Seeds from the F1 of the two crosses were analysed by two-dimensional electrophoresis and in both cases the CMe-1 variant coexisted with the CMe-2-2 ones (Fig. 7).

\section{Discussion}

The trypsin inhibitor sequenced by Odani et al. (1983) and protein CMe (Salcedo et al. 1984) had been found to be identical (Lazaro et al. 1985), and the corresponding gene had been located in chromosome 3H (Hejgaard et al. 1984; Salcedo et al. 1984). Besides trypsin inhibitor CMe, a second homologous trypsin inhibitor, designated CMc, had been identified in barley endosperm (Barber et al. 1986) and its gene assigned to chromosome $7 \mathrm{H}$ (Salcedo et al. 1984). The two trypsin inhibitors belong to a family which also includes inhibitors of heterologous $\alpha$-amylases (GarciaOlmedo et al. 1987). The cloned cDNA reported here (clone $\lambda \mathrm{CMe}$ ) clearly corresponds to the first inhibitor on the basis of the amino acid sequence deduced from it and the chromosomal location of DNA sequences with which it hybridizes.

In mature kernels of mutant Risø 1508 , trypsin inhibitor CMe is either absent or, at most, represents less than $2 \%-3 \%$ of the amount present in the wild type. This is in line with the observed steady-state levels of the corresponding mRNAs during endosperm development, which are about $1 \%$ in the mutant with respect to the wild type. The lower expression level is not brought about either by changes in copy number of the structural gene, as was the case for B-hordein in the hor-2ca mutation (Kreis et al. 1983), or by a major rearrangement of the gene, as judged by the unaltered restriction patterns in the mutant. Furthermore, the functional and regulatory properties of the gene have not been affected in the mutant because normal expression is observed in endosperms from reciprocal crosses between Risø 1508 and cv. Hatif de Grignon. Endosperm is a triploid tissue, where two genome complements are contributed by the mother. Thus, endosperms from the F1 (Rise $1508 \times$ Hatif) have two doses of the CMe-1 allele and one of the CM2-2' allele at the CMe locus in chromosome $3 \mathrm{H}$, and two doses of the mutant allele and one dose of the wild-type one at the regulatory lys $3 a$ locus in chromosome 7 (synonym $5 \mathrm{H}$ ). One dose of the wild-type allele at the regulatory locus is enough for the accumulation of normal levels of the CMe-1 protein. All this evidence indicates that the expression of gene $C M e$ is regulated in trans by the gene at the $l y s 3 a$ locus.
The effect of the lys $3 a$ mutation on gene $C M e$ seems to be rather specific because it does not negatively affect expression of the gene for the homologous amylase inhibitor BDAI-1, nor that of trypsin inhibitor CMc or those of the other known members of the same protein family (Salcedo et al. 1984; Lazaro et al. 1985). Other genes which have been reported to be negatively affected by the $l y s 3 a$ mutation, besides those encoding different hordeins, are those for protein $\mathrm{Z}$ and $\beta$-amylase (Balasaraswathi et al. 1984; Kreis et al. 1987). In contrast to these two proteins, which are greatly increased by the lys mutation in Hiproly barley (Hejgaard and Boisen 1980; Boisen et al. 1981; Hejgaard 1982), trypsin inhibitor CMe is also markedly decreased by the latter mutation (Lazaro et al. 1985). A structural and functional investigation of the promoter of gene CMe should contribute to a characterization of the $l y s 3 a$ regulatory locus. Since gene $C M e$ is expressed in the first half of endosperm development, while hordeins, protein $Z$ and $\beta$-amylase are mainly accumulated in the second half, the present results indicate that the $l y s 3 a$ locus must be active during most of the developmental period.

Acknowledgements. The technical assistance of L. Lamoneda, C. Rojas and J. Garcia is gratefully acknowledged. P. RodriguezPalenzuela was under a post-doctoral contract from the Centro Nacional de Biotecnologia. I Royo and L. Gómez were recipients of FPI scholarships from the Ministerio de Educación y Ciencia. This work was supported by grant Bjo88-0216 from the Comision Interministerial de Ciencia y Tecnologia.

\section{References}

Balasaraswathi R, Koie B, Doll $H$ (1984) The concentration and yield of hordein and some lysine-rich proteins as influenced by the lys gene of Hiproly barley. Hereditas 100:225-231

Barber D, Sanchez-Monge R, Mendez E, Lazaro A, Garcia-Olmedo $F$, Salcedo $G$ (1986) New $\alpha$-amylase and trypsin inhibitors among the CM-proteins of barley (Hordeum vulgare). Biochim Biophys Acta 869:115-118

Boisen S, Andersen CY, Hejgaard J (1981) Inhibitors of Chymotrypsin and microbial serine proteases in barley grains. Physiol Plant. 52:167-176

Brandt A (1976) Endosperm protein formation during kernel development of wild type and a high-lysine barley mutant. Cereal Chem 53:890-901

Doll $H$ (1973) Inheritance of the high-lysine character of a barley mutant. Hereditas 74:19-20

Doll H (1980) A nearly non-functional mutant allele of the storage protein locus $\mathrm{Hor} 2$ in barley. Hereditas 93:217-222

Doll H (1983) Barley seed proteins and possibilities for their improvement. In: Gottschalk W, Muller HP (eds) Seed proteins: biochemistry, genetics, nutritive value. Nijhoff, The Hague, pp 205-223

Doll $H$ (1984) Nutritional aspects of cereal proteins and approaches to overcome their deficiencies. Philos Trans R Soc London Ser B 304:373-380

Doll H, Køie B, Eggum BO (1974) Induced high-lysine mutants in barley. Radiat Bot 14:73-80

Domoney C, Casey R (1987) Changes in legumin messenger RNAs throughout seed development in Pisum sativum L. Planta $170: 562-566$

Feinberg AP, Vogelstein B (1983) A lechnique for radiolabeling DNA restriction endonuclease fragments to high specific activity. Anal Biochem 132:6-13

Garcia-Olmedo F, Salcedo G, Sánchez-Monge R, Gómez L, Royo J, Carbonero P (1987) Plant proteinaceous inhibitors of proteinases and $\alpha$-amylases. In: Miflin BJ (ed) Oxford Surveys of Plant 
Molecular and Cell Biology, vol 4. Oxford University Press, Oxford, pp 275-334

Hejgaard J (1982) Purification and properties of protein $\mathrm{Z}-\mathrm{a}$ major albumin of barley endosperm. Physiol Plant 54:174-182

Hejgaard J, Boisen S (1980) High-lysine proteins in Hyproly barley breeding: identification, nutritional significance and new screening methods. Hereditas $93: 319-320$

Hejgaard J, Björn SE, Nielsen G (1984) Localization to chromosomes of structural genes for the major protease inhibitors in barley grains. Theor Appl Genet 68:127-130

Hopp HE, Rasmussen SK, Brandt A (1983) Organization and transcription of B1 hordein genes in high lysine mutants of barley. Carlsberg Res Commun 48:201 -210

Ingversen J, Koie B, Doll H (1973) Induced seed protein mutant of barley. Experientia $29: 1151-1152$

Islam AKMR, Shepherd KW, Sparrow DHB (1978) Production and characterization of wheat-barley addition lines. Proc 5th Int Wheat Genet Symp, pp 365-371

Karlsson KE (1976) Linkage studies on the lys gene in relation to some marker genes and translocations. In: Gaul $\mathrm{H}$ (ed) Barley Genetics III. Verlag Karl Thiemig, Munich, FRG, pp 536541

Karlsson KE (1977) Linkage studies in a gene for high lysine content in Riso barley mutant 1508. Barley Genet Neslett 7:40-43

Kreis M, Shewry PR, Forde BG, Rahman S, Miflin BJ (1983) Molecular analysis of a mutation conferring the high lysine phenotype on the grain of barley (Hordeum vulgare). Cell 34:161-167

Kreis M, Shewry PR, Forde BG, Rahman S, Bahramian MB, Miflin BJ (1984) Molecular analysis of the effects of the mutant lys $3 a$ gene on the expression of Hor loci in developing endosperms of barley (Hordeum vulgare). Biochem Genet 42:231-255

Kreis M, Williamson M, Buxton B, Pywell J, Hejgaard J, Svendsen 1 (1987) Primary structure and differential expression of $\beta$-amylase in normal and mutant barleys. Eur J Biochem 169:517-525

Lazaro A, Barber D, Salcedo G, Mendez E, Garcia-Olmedo F (1985) Differential effects of high lysine mutations on the accumulation of individual members of a group of proteins encoded by a disperse multigene family in the endosperm of barley (Hordeum vulgare L.). Eur J Biochem 149:617-623

Lazaro A, Rodriguez-Palenzuela P, Maraña C, Carbonero P, Garcia-Olmedo $F$ (1988 a) Signal peptide homology between the sweet protein thaumatin II and unrelated cereal $\alpha$-amylase/trypsin inhibitors. FEBS Lett 239:147-150

Lazaro A, Sanchez-Monge R, Salcedo G, Paz-Ares J, Carbonero $P$, Garcia-Olmedo $F$ ( 1988 b) A dimeric inhibitor of insect $\alpha$ amylase from barley. Cloning of the cDNA and identification of the protein. Eur J Biochem 172:129-134

Maniatis T, Fritsch EF, Sambrook J (1982) Molecular cloning: a laboratory manual. Cold Spring Harbor Laboratory, Cold Spring Harbor, New York

Maxam AM, Gilbert W (1980) Sequencing end-labeled DNA with base-specific chemical cleavages. Methods Enzymol 65:499-560
Mertz ET, Bates LS, Nelson OE (1964) Mutant gene that changes protein composition and increases lysine content of maize endosperm. Science 145:279-280

Munck L, Karlsson KE, Hagburg A, Eggum BO (1970) Gene for improved nutritional value in barley seed protein. Science 168:985-987

Murray MG, Thompson WF (1980) Rapid isolation of high molecular weight plant DNA. Nucleic Acids Res 8:4321-4325

Nelson OE, Mertz ET, Bates LS (1965) Second mutant gene affecting the amino acid pattern of maize endosperm proteins. Science 150:1469-1470

Odani S, Koide T, Ono T (1983) The complete amino acid sequence of barley trypsin inhibitor. J Biol Chem 258:7998-8003

Paz-Ares J, Ponz F, Aragoncillo C, Hernández-Lucas C, Salcedo $G$, Carbonero $P$, Garcia-Olmedo $F$ (1983) In vivo and in vitro synthesis of CM-proteins (A-hordeins) from barley (Hordeum vulgare L.). Planta 157:84-80

Paz-Ares J, Ponz F, Rodriguez-Palenzuela P, Lazaro A, Hernández-Lucas C, Garcia-Olmedo F, Carbonero P (1986) Characterization of cDNA clones of the family of trypsin/ $\alpha$-amylase inhibitor (CM proteins) in barley (Hordeum vulgare L.). Theor Appl Genet $71: 842-846$

Salcedo G, Fra-Mon P, Molina-Cano JL, Aragoncillo C, GarciaOlmedo F (1984) Genetics of CM-proteins (A-hordeins) in barley. Theor Appl Genet 68:53-59

Sanger F, Nicklen S, Coulson AR (1977) DNA sequencing with chain-terminating inhibitors. Proc Natl Acad Sci USA $74: 5463-5467$

Shewry PR, Faulks AJ, Miflin BJ (1980) Effects of high-lysine mutations on the protein fractions of barley grain. Biochem Genet 18:133-151

Singh R, Axtell JD (1973) High lysine mutant gene (hl) that improves protein quality and biological value of grain sorghum. Crop Sci 13:535-539

Sogaard B, von Wettstein-Knowles P (1987) Barley: genes and chromosomes. Carlsberg Res Commun 52:123-196

Sørensen MB, Cameron-Mills V, Brandt A (1989) Transcriptional and post-transcriptional regulation of gene expression in developing barley endosperm. Mol Gen Genet 217:195-201

Thompson R, Bartels D (1983) Hordein messenger RNA levels in wild type and mutant barley endosperm. Plant Sci Lett 29:295-304

Woods DE, Markham AF, Ricker AT, Goldberg G, Cotten HR (1982) Isolation of cDNA clones for the human complement protein factor B, a class III major histocompatibility complex gene product. Proc Natl Acad Sci USA 79:5661-5665

Yamamoto KR, Alberts BM, Benzinger R, Lawhorne L, Treiber $G$ (1970) Rapid bacteriophage sedimentation in the presence of polyethylene glycol and its application to large scale virus purification. Virology 40:7434-7439

Communicated by $\mathrm{H}$. Saedler 